\title{
Estimation of Total Phenol Content and Antimicrobial Activity in Different Leaf Stage of Lepisanthes amonea
}

\author{
Frika Purnamasari ${ }^{1}$ Harlinda Kuspradini ${ }^{1, *}$ Tohru Mitsunaga $^{2}$ \\ ${ }^{I}$ Faculty of Forestry, Mulawarman University, Jl. Ki Hajar Dewantara Kampus Gunung Kelua Samarinda, \\ Kalimantan Timur, Indonesia \\ ${ }^{2}$ Faculty of Applied Biological Science, Gifu University, Japan \\ "Corresponding author. Email: alinkuspra@gmail.com
}

\begin{abstract}
Many plants have been reported to possess antibacterial activity, and among them are coming from the Sapindaceae family. The Sapindaceae family has 2,215 species in 147 genera. L. amoena is one species in this family found in East Kalimantan. This study's objective was to determine the effect of the leaf stage on phenolic composition and antimicrobial activity. The powder of L. amoena was extracted by successive maceration using hexane, ethyl acetate, and ethanol. In this study, the polyphenolic content of the different extracts was determined by the Folin-Ciocalteu method. Their antimicrobial activity was assayed through in vitro models such as agar dilution assay. The anti microorganism of different leaf stage from L. amoena extracts towards Streptococcus mutans, Propionibacterium acnes, and Candida albicans growth were determined. The results showed that Lepisanthes amoena extracts could inhibit the growth of those bacteria. The expression level of inhibitory effect on bacteria's growth was reduced by increasing the concentration of extract. The leaves at a particular stage may have more antimicrobial potential. The leaf maturity played essential roles in the bioactive compounds and their antimicrobial of L. amoena leaf extract.
\end{abstract}

Keywords: Lepisanthes amoena, Polyphenol, Antimicrobial activity

\section{INTRODUCTION}

Sapindaceae are a reasonably large family of main trees, shrubs, and lianas, primarily tropical or subtropical. The most important center of diversity appears to be in the Southeast Asian region. Within Australia, Sapindaceae from a significant rainforest environment component, with most of the 30 genera restricted to the northern tropical region, with a few species extending down the coast within subtropical rainforest [1]. The genus Lepisanthes (Sapindaceae) consists of 24 species and widely distributed from India and Sri Lanka in the west, Malaysia, and the Philippines and Papua New Guinea in the east. Out of these, five species can be found in Malaysia. They are L. amoena, $L$. fruticosa, $L$. tetraphylla, $L$. rubiginosa, and $L$. senegalensis. These species are usually planted and conserved for its edible fruits, while others are still thriving in the wild. A few Lepisanthes species such as $L$. fruticosa and $L$. rubiginosa are usually consumed as a food source and used in traditional medicine by rural folks [2].
With the rising prevalence of microorganisms showing resistance to antibiotics, there is an urgency to develop new anti-microorganism compounds since antiquity; plants have been used to treat common infectious diseases. The healing potential of many plants has been utilized by public traditional [3]. L. amoena is one of the potential plants as medicinal plants. Traditionally, the local people used the young leaves as skincare. Empirically, L. amoena has been used by Kutai, Dayak Tunjung, and Dayak Benuaq in East Borneo in cosmetics and medicine preparation, such as a traditional face powder protect the skin during work in the fields from the sun [4]. Therefore, our objectives were to evaluate the antibacterial activity of young, semi-mature, and mature leaves. In addition, we also compared the phenolic content in $n$-hexane, ethyl acetate, and methanol extract of leaves. 


\section{MATERIAL AND METHOD}

\subsection{Extraction}

L. amoena leaves were cleaned and chopped into small pieces. After drying the samples of leaves, $L$. amoena blended to a powder. L. amoena leaf powder was macerated with $n$-hexane. Then the residue of nhexane is macerated with ethyl acetate to get ethyl acetate extract. Ethyl acetate residue subsequently macerated with ethanol. The filtrate hexane, ethyl acetate, and ethanol subsequent the filtrates using a rotary evaporator with the water bath set at $39-40^{\circ} \mathrm{C}$.

\subsection{Anti-microorganisms Activity}

The testing performed using the diffusion method [5]. In this test, $30 \mathrm{ml}$ media petridish Natrium Agar was poured into a sterilized for 30 minutes at $121^{\circ} \mathrm{C}$ temperatures in the autoclave. The test microbe was taken from the broth culture with an inoculating loop and transferred to a test tube containing $5.0 \mathrm{~mL}$ sterile distilled water. The cotton swab was then used to inoculate the test tube suspension onto the nutrient broth agar plate's surface, and the plate was allowed to dry. Once the plates had been dried, six mm-diameter wells were bored in each dish by removing the agar using a sterile cork borer, then immediately filled with the test and control materials (one well for each substance). Control $(20 \mu \mathrm{l})$ or extracts with different amount of samples $(100 \mu \mathrm{g}, 200 \mu \mathrm{g}$, and $300 \mu \mathrm{g})$ were placed into the wells. The fungal spores used were Candida albicans. The bacteria used were Propionibacterium acnes and Streptococcus mutans.

\subsection{Determination of total phenolic contents (TPC)}

Total phenolic contents were determined using the Folin-Ciocalteu reagent [6]. The crude extract $(1 \mathrm{mg})$ was combined with Folin-Ciocalteu reagent $(0.25 \mathrm{ml})$ and deionized water $(0.4 \mathrm{ml})$. After $10 \mathrm{~min}, 1.25 \mathrm{ml}$ of $7.5 \%$ sodium carbonate (w/v) was added. Then the mixture was incubated for $60 \mathrm{~min}$. The absorbance of the blue-colored solution was measured at $760 \mathrm{~nm}$ using a spectrophotometer. The amount of TPC was expressed as gallic acid equivalents (GAE) $\mathrm{mg} / \mathrm{g}$ dry weight.

\section{RESULT AND DISCUSSION}

The various extract solutions' absorbance values reacted with the Folin-Ciocalteu reagent and calculated with the gallic acid curve's standard solutions $\left(\mathrm{R}^{2}=0.9782\right)$. The results show that the content of total phenols in the investigated extracts ranged from 0.04 to $0.87 \mathrm{mg} \mathrm{GAE} / \mathrm{g}$ dry weight. The results showed that the lowest and highest content of total phenols is obtained in the extract of young leaves-ethyl acetate extract $(0.04$ $\mathrm{mg}$ GAE/g dry weight) and mature leaves-ethanol extract $(0.87 \mathrm{mg}$ GAE/g dry weight), respectively. Overall, mature leaves' anti-organic microorganism activity was higher than the semi-mature and young leaves (except in $S$. mutans). The highest inhibition zone against $P$. acnes $(12.00 \pm 0.00 \mathrm{~mm})$ and $C$. albicans $(16.11 \pm 0.19 \mathrm{~mm})$ were in mature leaves-ethanol extract while the highest inhibition zone against $S$. mutans $(18.33 \pm 0.72 \mathrm{~mm})$ were in the semi-mature leaves-hexane extract.

Table 1. Total phenolic content and anti microorganism activity of Lepisanthes amoena at $300 \mu \mathrm{g} / \mathrm{well}$

\begin{tabular}{lcccc}
\hline \multirow{2}{*}{ Extracts } & Phenolic content & \multicolumn{3}{c}{ Inhibition zone $(\mathrm{mm})$} \\
\cline { 4 - 5 } & mg GAE/g dry weight & S. mutans & P. acnes & C. albicans \\
\hline Young Leaf & $0.08 \pm 0.01$ & $14.77 \pm 2.21$ & - & $12.66 \pm 0.33$ \\
Hexane & $0.04 \pm 0.00$ & $12.11 \pm 0.38$ & - & $10.88 \pm 0.38$ \\
Ethyl acetate & $0.33 \pm 0.00$ & $14.44 \pm 0.19$ & $10.55 \pm 0.19$ & $10.66 \pm 1.00$ \\
Etanol & & & & \\
Semi Mature & $0.07 \pm 0.01$ & $18.33 \pm 0.72$ & $9.56 \pm 0.58$ & $11.56 \pm 1.41$ \\
Hexane & $0.27 \pm 0.01$ & $17.67 \pm 0.89$ & $10.44 \pm 0.58$ & $13.67 \pm 1.03$ \\
Ethyl acetate & $0.86 \pm 0.02$ & $14.44 \pm 0.58$ & $11.67 \pm 0.58$ & $12.33 \pm 0.72$ \\
Etanol & & & & $14.55 \pm 0.96$ \\
\hline Mature & $0.16 \pm 0.02$ & $12.44 \pm 1.71$ & $10.88 \pm 0.69$ & $15.55 \pm 0.38$ \\
Hexane & $0.22 \pm 0.01$ & $14.00 \pm 0.33$ & $11.22 \pm 0.38$ & $16.11 \pm 0.19$ \\
Ethyl acetate & $0.87 \pm 0.02$ & $14.88 \pm 1.07$ & $12.00 \pm 0.00$ & \\
Etanol & & & & \\
\hline
\end{tabular}


Lepisanthes amoena (Hassk.) Leenh. plant leaves are used by the Dayak tribe of East Kalimantan as traditional cosmetics ingredients. This plant has antimicrobial properties and antiacne, antifungal, antioxidant, and antityrosinase [7-11]. On the other hand, the antimicrobial activity and the total phenolic content of L. amoena leave in this study had a positive linear correlation. The correlation between the antimicrobial activity and total phenolic compounds was reported by other authors [12]. Most phenolics that display antimicrobial activity are phenolic acids. Phenolic acids are a significant class of phenolic compounds occurring in various plants [13]. The phenolic moiety also plays a vital role in determining a plant's antimicrobial activity [14]. The antimicrobial activity of L. amoena from ethanol suggests their ability to extract polyphenolic compounds such as simple phenol, anthocyanin, phenylpropanoids, and flavonol [15].

\section{CONCLUSION}

It may be suggested that the maturity of leaves involves the phenolic content and microorganism inhibition. The result obtained regarding the anti microorganism in this study should help the further use the L. amoena medicinal plant as a treatment for the skin.

\section{REFERENCES}

[1] M.G. Harrington, Phylogeny and Evolutionary History of Sapindaceae and Dodoneae, PhD Thesis, School of Marine \& Tropical Biology, James Cook University, 2008. Available at http://eprints.jcu.edu.au/7893.

[2] A.N. Ghazalli, N. Thalib, A.L. Mohammad, Leaf micro-morphology of Lepisanthes Blume (Sapindaceae) in Peninsular Malaysia. AIP Conference Proceedings 1940, 020038, 2018. DOI: 10.1063/1.5027953.

[3] A. Jayashree, S. Maneemegalai, Studies on the antibacterial activity of the extracts from Tridax procumbens $\mathrm{L}$ and Ixora coccinea L., Biomedicine, 28, 2008, pp. 190-194.

[4] H. Warnida, H. Nurhasnawati, Efektivitas Ekstrak Daun Kokang (Lepisanthes amoena) Sebagai Tabir Surya; Eksplorasi Kearifan Lokal Kalimantan Timur, Jurnal Penelitian Ekosistem Dipterokarpa, 3(2), 2017, pp. 57-62. DOI: http://dx.doi.org/10.20886/jped.2017.3.2. 57-62. [Indonesian]

[5] I.W. Kusuma, Murdiyanto, E.T. Arung, Syafrizal, Y-u. Kim, Antimicrobial and antioxidant properties of medicinal plants used by the Bentian tribe from Indonesia. Food Sci. Hum. Wellness. 3(34), 2014, pp. 191-196. DOI: https://doi.org/10.1016/j.fshw.2014.12.004.

[6] A. Chaovanalikit, R.E. Wrolstad, Total Anthocyanins and Total Phenolics of Fresh and Processed Cherries and Their Antioxidant Properties, Journal of Food Science, 69, 2004, pp. 67-72.

[7] I. Batubara, T. Mitsunaga, H. Ohashi, Screening antiacne potency of Indonesian medicinal plants: antibacterial, lipase inhibition, and antioxidant activities, J Wood Sci, 55, 2009, pp. 230-235.

[8] H. Kuspradini, D. Susanto, T. Mitsunaga, Phytochemical and comparative study of anti microbial activity of Lepisanthes amoena leaves extract, J. Biol. Agric. Healthc, 2(11), 2012, pp. 80-86.

[9] H. Warnida, Skrining Fitokimia dan Aktivitas Antibakteri Ekstrak Etanol Daun Kokang (Lepisanthes amoena (Hassk.) Leenh.) Terhadap Staphylococcus epidermidis, Seminar Nasional Akademi Farmasi Samarinda, 2016, pp. 12-18.

[10] H.D. Salusu, F. Ariani, E. Obeth, M. Rayment, E. Budiarso, I.W. Kusuma, E.T. Arung, Phytochemical screening and antioxidant activity of selekop (Lepisanthes amoena) fruit, Agrivita, 39(2), 2017, pp. 214-218. DOI: https://doi.org/10.17503/agrivita.v39i2.810.

[11] E.T. Arung, W.F. Pasedan, I.W. Kusuma, M. Hendra, M.B. Supriadi, Short communication: Selected medicinal plants in east and North Kalimantan (Indonesia) against Propionibacterium acnes, Biodiversitas, 18(1), 2017, pp. 321-325. DOI: https://doi.org/10.13057/biodiv/d180142.

[12] N.G. Baydar, G. Özkan, O. Sagdic, Total phenolic contents and antibacterial activities of grape (Vitis vinifera L.) extracts, Food Control, 15, 2004, pp. 335-339.

[13] A. Wojdylo, J. Oszmianski, R. Czemerys, Antioxidant Activity and Phenolic Compounds in 32 Selected Herbs, Food Chem, 105, 2007, pp. 940-949.

[14] A. Kujumgiefv, V. Bankova, A. Ignatova, S. Popov, Antibacterial activity of propolis, some of its components and their analogs, Pharmazie, 48, 1993 , pp. 785-786.

[15] N. Shahina, A. Samia, A.R. Sheikh, S. Rahmatullah, Research J. of Microbiol., 2, 2007, pp. 180-184. 